"Burnout, inter-role conflicts, and job performance among bankers who have children during social isolation"

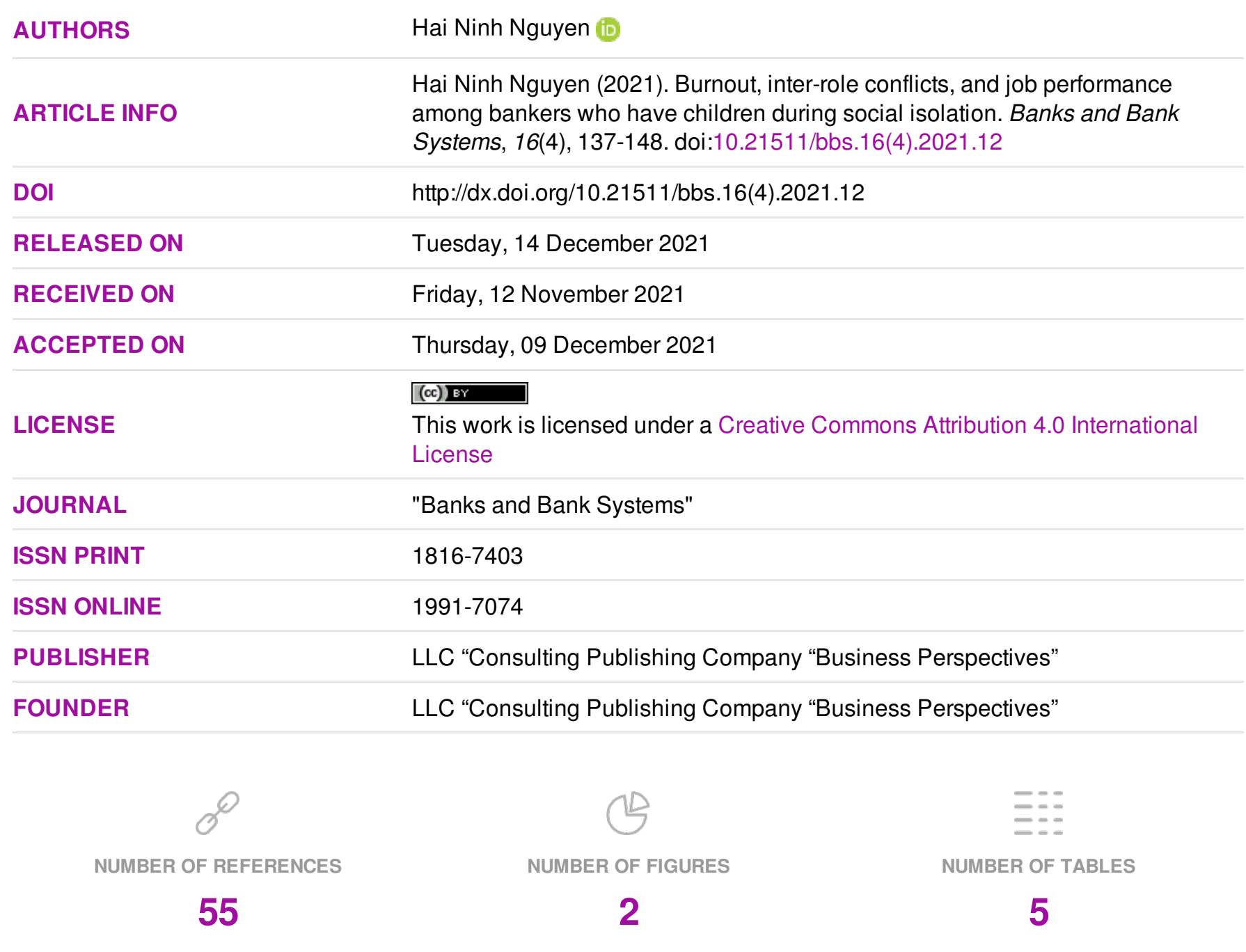

(C) The author(s) 2021. This publication is an open access article. 


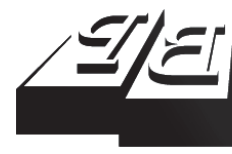

\section{BUSINESS PERSPECTIVES}

9

LLC "CPC "Business Perspectives" Hryhorii Skovoroda lane, 10, Sumy, 40022, Ukraine www.businessperspectives.org

Received on: $12^{\text {th }}$ of November, 2021 Accepted on: $9^{\text {th }}$ of December, 2021 Published on: $14^{\text {th }}$ of December, 2021

(C) Hai Ninh Nguyen, 2021

Hai Ninh Nguyen, Dr., School of International Business and Economics, Department of Marketing and Communications, Foreign Trade University, Vietnam.

\title{
BURNOUT, INTER-ROLE CONFLICTS, AND JOB PERFORMANCE AMONG BANKERS WHO HAVE CHILDREN DURING SOCIAL ISOLATION
}

\begin{abstract}
Social isolation is a globally accepted policy of governments worldwide to halt the rapid spread of coronavirus in the community. As a result, all banks must be closed, and bank officers must work from home through the Internet instead of at their offices. Hence, stressors and conflicts wreak havoc on bank officers' mental health and work productivity. This study focused on determining the influence of burnout and inter-role conflicts on the working performance of bankers who have got children. An online structured questionnaire was utilized to survey 326 bankers throughout the nation. The PLS-SEM and Smart PLS were adopted to analyze and test hypotheses. The findings corroborated the harmful effects of burnout and inter-role conflicts on the job performance of bankers who have got children. Three variables were determined to positively affect burnout, such as occupational stress, parenting stress, and inter-role conflicts, whereas the role ambiguity and role overload sparked the inter-role conflicts of bankers. This study recommended four practical suggestions for both bankers and banks' policymakers, including: achieving work-family balance is a challenging task; the need to implement more robust organizational support policies to remove the burden and job-stressors; the administrative workload should be reduced and cut off; and bankers individually should get familiar with saying "No" to the unimportant and taking care of themselves during pandemic isolation.
\end{abstract}

Keywords

JEL Classification

\section{INTRODUCTION}

To prevent the fast and uncontrollable transmission of coronavirus in the community, governments worldwide implemented a series of strict policies such as requiring people to wear medical masks, stop gathering in public places, and finally, apply physical distancing restrictions. The social isolation ranged from partial to complete lockdowns based on the actual situation of each country. Under the requirements of social isolation, businesses, offices, banks, factories, schools, and public places were forced to close or scale down. Therefore, to maintain operations, working from home has become a mandatory requirement for employees, regardless of sectors and industries. As mentioned in Cluver et al. (2020), though social distancing policies and working from home instead of going to the office help reduce virus transmission in the community, they may also cause many difficulties and troubles for employees. However, being praised and predicted to be the future working format, working from home has not been a good solution for all businesses and sectors. Without colleagues' support 
and guidance from leaders, employees must manage mountains of work independently. In the long run, the pressure from work will create an uncomfortable feeling and lead to burnout.

Garbe et al. (2020) stated that parents must struggle to get all job tasks done while caring for their children and fulfilling other housework. Moreover, parents have been doing housework and cooking, taking care of children, and instructing their children to study. These responsibility burdens have reduced work efficiency and caused stressors and fatigue for parents. Imagined that a bank officer was in an important meeting with the heads of bank departments and enterprise partners, it would be hard for her to concentrate on the discussion as her toddler is screaming, crying, and the older one is throwing toys to the television. The scene was horrible to everyone, especially bankers whose works closely stick to money. Hence, working from home is almost exclusively suitable for fields that do not require direct interactions. As for the fields that need exchange and human interaction, this format causes individual depression, burnout symptoms, reduced working productivity, losing job performance, and conflicts in family life (Chung et al., 2020).

Many bankers, including bankers who have children, must work from home as the strict control of social isolation; thus, they have experienced problems and limitations of working from home through some support and encourage this working model. Work-from-home is argued to save time and enhance employees' autonomy and self-control of working tasks and progress. However, there are many complaints about the work efficiency and employees' concentration when working online (Ammons \& Marham, 2004). Additionally, financial and banking jobs are professions that require seriousness, integrity, and high concentration. Therefore, bankers who have children have experienced many problems balancing work and life during COVID-19 social distancing.

\section{LITERATURE REVIEW AND HYPOTHESES DEVELOPMENT}

There have been several approaches to job performance both in literature and practice. In manufacturing and business organizations, employee job performance has been evaluated by workers' productivity, sales, revenue, and market share. Osman et al. (2016) stated that job performance is a fundamental indicator of employee effectiveness, i.e., sales, revenue, number of new customers. The financial indicators seem to be easier to assess, while Nilsen and Ringholm (2019) stated that the nonfinancial aspects such as employee satisfaction, work motivation, organizational commitment, and absenteeism must also be considered.

Job performance was stated by Saetang et al. (2010) as a human behavior used to evaluate individual work effectiveness. Hence, job performance is the leading cause of organizational success. Supporting the idea of considering job performance as human behavior, Ajila and Abiola
(2017) argued that a worker's performance on the job could be measured, analyzed, and evaluated on an individual basis. For workers who work alone or on self-assessment rather than by a supervisor or management, this technique stressed the self-rated job performance, so-called "perceived job performance," and this group includes bankers. As defined by Deadrick and Gardner (1999), job performance is the sum of all the work done by an employee in the course of a specific period. In this perspective, job performance is used to evaluate employees' attempts to execute their work tasks. Job performance has two dimensions: extra- and intra-role behavior (Katz \& Kahn, 1978), or task/contextual performance (Borman \& Motowidlo, 1997).

Burn-out is the first expressed by Freudenberger (1974), representing psychological stress syndrome. During some recent decades, burnout syndrome attracted the concerns of both scholars and practitioners as burnout has become a long-term unsolved issue and harms a person (Koronaiou \& Antoniou, 2017). Although most people have ever experienced burnout symptoms, there is no universally accepted meaning 
for this terminology. In the psychology literature, scholars have proposed several different definitions. Honkonen et al. (2000) proposed that burnout is a condition that might negatively influence one's physical and psychological well-being. Katz and Kahn (1978) also emphasized that burnout is the leading cause of negative attitudes toward others and self. In the workplace context, because of long-term stress at work, burnout occurs when mental and emotional resources are depleted (Schaufeli \& Enzmann 1998). Maslach et al. (2001) described burnout as a psychological disorder brought on by long-term interpersonal stresses at a job. Emotional fatigue, depersonalization (an attitude of cynicism and distance from one's profession), and a sense of inadequacy are all signs of burnout, according to Maslach et al. (2001).

It was observed that Jackson and Schuler (1983) described burnout as an emotional and psychological process that an employee goes through due to the work and personal lives, which was found to be consistent with the findings of this study. According to this definition, burnout happens when a person becomes mentally weary and worn out because of excessive demand, which can be imposed both inwardly and externally. The "internal" was named personal experiences, whereas the "external" refers to the job-related experiences. The role conflicts, the overall work/family conflicts, and the emotional load are three determinants of burnout in the study of Ahuja et al. (2007), whereas Fujiwara et al. (2003) added inter-personal relationships conflict to the causes of burnout. The research on organizational behavior has established that burnout is a factor in declining organizational commitment (Lee \& Ashforth, 1996), and work performance suffers (Tubre \& Collins, 2000). Moreover, burnout also cause the turnover intention of employees (Cropanzano et al., 2003).

To be successful in their professions, employees must continuously strike a balance between the demands of their jobs and the demands of their personal lives. Inter-role conflict is frequently the outcome of these clashing demands and obligations. Inter-role conflict occurs when meeting the needs of two or more parties is more complex than meets the demands of just one
(House \& Rizzo, 1972). According to Kremer (2016), inter-role conflict happens when people take on many roles at the same time and are unable to handle the responsibilities that come with each one. However, more and more people are taking on many responsibilities at the same time. Many studies on employee-organizational commitment use the term "work-family conflict" (WFC) to describe conflicts between work and home duties, while "family-work conflict" (FWC) is used to describe conflicts between the roles of a worker and his or her family.

Disputes between roles can emerge when the demands of a career and family responsibilities are conflicting circumstances (Lu et al., 2019). When employees perceive an overabundance of family responsibilities, which correlate with inter-role conflict, they may develop a sense of family overload. Furthermore, overloading employees and inter-role conflict are likely to result in various dysfunctional effects, including employee unhappiness, decreased performance, and psychological distress. (Jawahar et al., 2012). The inter-role conflict has also been confirmed to positively correlate with emotional exhaustion, the propensity to quiet, and tension.

A worker's physical and emotional reactions might be regarded as a form of occupational stress when the worker's abilities, resources, or needs do not fit the job's specifications (De Silva et al., 2017). To Bolman and Deal (2017), occupational stress is the state of being overwhelmed and unable to deal with the responsibilities of one's job. As discussed by Arnold et al. (2005), occupational stress is an escalating hazard, especially among professionals. Bankers' occupational stress is attributed to their workload, and occupational stress often leads to unpleasant emotions such as depression and anxiety - dominant symptoms of burnout. Drake and Hebert (2002) drafted the strategies to avoid burnout in which occupational stress is the sole antecedent of the burnout syndrome. Sriharan et al. (2021) supported this idea by affirming the strong impact of occupational stress on women's burnout in the healthcare sector during COVID-19 in their recent research.

Just being a parent may cause a lot of emotional and mental strain (Berry \& Jones, 1995). 
According to Raphael et al. (2010), when a parent's expectations and resources are out of whack, they are experiencing parental stress. According to Holly et al. (2019), when parents are presented with parental demands yet lack the resources to meet those demands, the stress in parenting is characterized as a psychological reaction. This point of view has been confirmed. All experts and practitioners agreed that parenting is a challenging profession that frequently causes mothers' and dads' stress (Deater-Deckard \& Scarr, 1996). These adverse psychological troubles may be amplified during home detention when external assistance is nonexistent and parents are personally affected (Giannotti et al., 2021). Both Holly et al. (2019) and Chung et al. (2020) affirmed the strict parental stress on the parents' life satisfaction, work commitment, and psychological well-being. Especially during the lockdown period, parenting stress is the leading cause of stress and burnout among employees who must work from home and balance the work tasks with housework simultaneously.

As discussed by Kahn et al. (1964), role overload occurs when a person is given a job or direction from their supervisors that is difficult to do within a specific time range and under defined quality standards. When an individual believes that he or she lacks the time or energy necessary to fulfill all the family's anticipated duty functions, he/she is experiencing role overload. For example, a person who takes care of children and spend time preparing lectures will probably struggle to manage time and efforts efficiently. Due to all duties that consume their time and focus. Hence, the performance of both duties may not be as good as expected. According to Ryan (2008), role overload frequently results in an increase in reported sensations of inter-role conflict, which is described as a clash of individual and social performance standards in which compliance with one set of performance expectations influences the performance of the other. In Gurbuz et al. (2013), the specific type of inter-role conflict was identified as two causes of work/family conflict: role overload and job stress.

Role ambiguity is another kind of role stress that may be used to explain employee conflict and burnout. Role ambiguity is the uncertain- ty in completing role-associated work, including role expectations and behaviors (Abramis, 1994). According to Kahn et al. (1964), uncertainty emerges when an employee does not understand his role expectations and is unsure of what he is expected to know about his responsibilities. As a result, one is unsure about what to do next. Role ambiguity occurs when the employee's responsibilities are not clearly defined, or if the roles and responsibilities have changed over time (Srivastav, 2006). A high level of stress might result from an employee's lack of assurance for the part they are expected to play and their lack of comprehension of the job's duties. (Netemeyer et al., 1990). Role ambiguity is always found in the research of work-related issues. Role ambiguity and role overload also positively impact the overall inter-role conflict. Role ambiguity is the potential source of aggression. The reasons for ambiguity vary, first, due to improper instructions from the supervisor, manager, or work colleagues. Second, misunderstanding between the tasks of the assigned person and executed person. Unclear information and expectations might be the primary roots of failure.

This study's primary goal is to understand better the effects of burnout and inter-role conflicts on the overall job performance of bankers who have children during the social distancing of COVID-19. Two main proposed antecedents of burnout are parental stress and occupational stress, whereas the inter-role conflict was proposed to determine by role ambiguity and role overload. Hence, seven hypotheses and a research model are proposed to examine and explore these relationships, namely:

H1: Burnout significantly impacts the job performance of bankers who have children.

H2: Inter-role conflict significantly impacts the job performance of bankers who have children.

H3: Inter-role conflict significantly impacts the burnout of bankers who have children.

H4: Occupational stress significantly impacts the burnout of bankers who have children. 


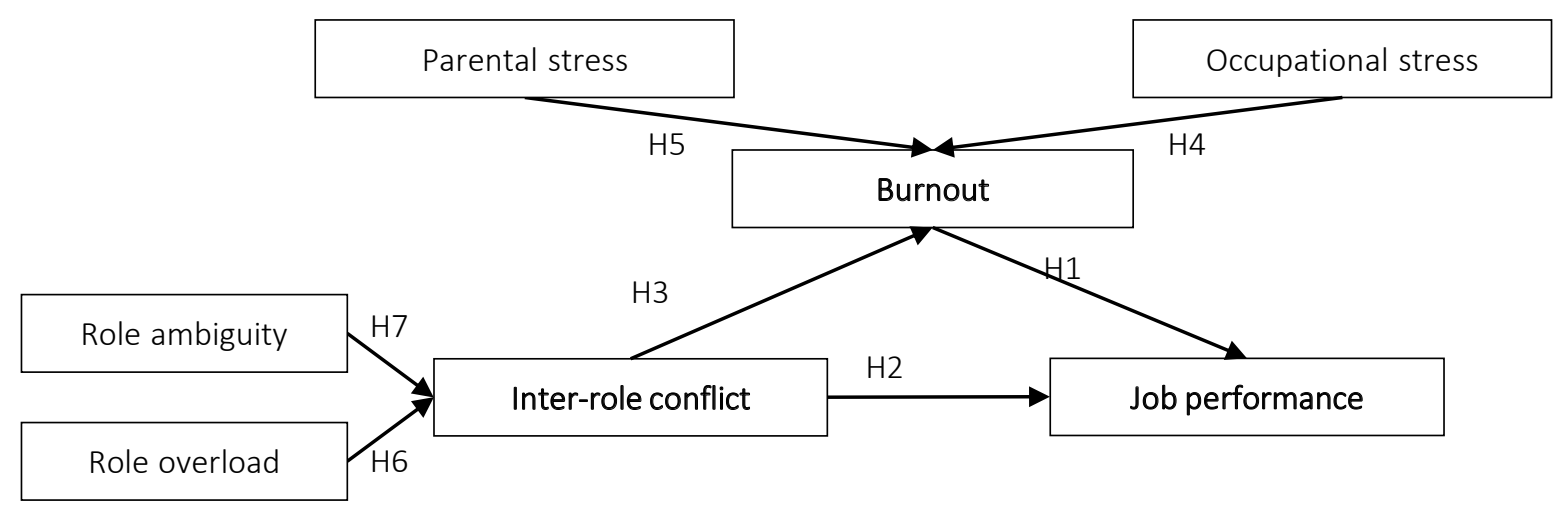

Figure 1. Research model

H5: Parental stress significantly impacts the burnout of bankers who have children.

H6: Role overload significantly impacts the burnout of bankers who have children.

H7: Role ambiguity significantly impacts the inter-role conflicts of bankers who have children.

\section{METHODS}

This study employed a quantitative research design. Descriptive and statistical analyses were conducted using Microsoft Excel, PLS-SEM, and Smart PLS. The PLS-SEM analysis technique is suggested by Andersen and Kheam (1988) to be executed via a process of two steps. First, the measurement model would be evaluated by examining these indicators such as Cronbach Alpha, Composite Reliability, and Convergent validity analysis. Second, the structural model would be examined by taking the bootstrap analysis procedure. There were both direct and indirect impacts examined by examining this structural model. Path coefficient, R-squared (R2), and predictive relevance evaluated the hypotheses $(\mathrm{Q} 2)$. The measurement constructs of this study were developed after reviewing the literature of psychology, social science, and especially human resource management. Bankers who have children and experts were consulted to adjust the scales fitting with the Vietnamese banking sector context.

The items of occupational stress measure the job-related stress feelings. These were selected and combined from the stress inventory devel- oped by Fimian (1984) and some other updated versions of Boyle et al. (1995). The Parental stress scale measures the perceptions of stress among bankers associated with having children from Berry and Jones (1995) items. The burnout construct was taken from Maslach and Jackson (1981). The inter-role conflict was developed from the items of Netemeyer et al. (1990); Role overload was adapted from Gurbuz et al. (2013), whereas Role ambiguity constructs developed from the items of Bowling et al. (2017). The job performance is adapted from the scale of Nguyen and Tran (2021). All measurement items were initially written in English and reviewed for content validity by a group of researchers. To ensure that they could be compared, they have first translated from English into Vietnamese and then back into English again. The wording of the Vietnamese version was discussed and polished to fit with the local context. The pretest questionnaire was distributed to 50 respondents to examine the scale's psychometric properties and evaluate the validity and reliability. After pretesting, statements were revised based on feedback, then problematic indicators were removed, resulting in 34 items.

Respondents are bankers who have children. They are working at banks, both state-owned banks and commercial banks in Vietnam. The non-probability technique - the convenience sampling method was applied. The preliminary test has been conducted online with 500 bankers who have children of 35 banks across the nation from July 2020 to March 2021 due to the social distancing restrictions and getting back 417 completed surveys. After cleaning and checking, 326 survey responses were finally accepted for analysis (78.2\%). 
Table 1. Demographical analysis of the respondents

\begin{tabular}{|c|c|c|c|}
\hline \multicolumn{2}{|c|}{$N=326$} & \multirow{2}{*}{$\frac{\text { No. }}{118}$} & \multirow{2}{*}{$\frac{(\%)}{36.20 \%}$} \\
\hline & Male & & \\
\hline Gender & Female & 208 & $63.80 \%$ \\
\hline \multirow{3}{*}{ Age } & $23-35$ & 74 & $22.70 \%$ \\
\hline & $36-45$ & 158 & $48.47 \%$ \\
\hline & $>45$ & 94 & $28.83 \%$ \\
\hline \multirow{2}{*}{ Position } & Front office & 265 & $81.29 \%$ \\
\hline & Back office & 61 & $18.71 \%$ \\
\hline \multirow{4}{*}{ Tenure } & $<3$ years & 42 & $12.88 \%$ \\
\hline & $3-7$ years & 94 & $28.83 \%$ \\
\hline & $7-10$ years & 138 & $42.33 \%$ \\
\hline & $>10$ years & 52 & $15.95 \%$ \\
\hline \multirow{2}{*}{$\begin{array}{l}\text { Number of } \\
\text { children }\end{array}$} & More than 2 & 73 & $22.39 \%$ \\
\hline & 1-2 children & 253 & $77.61 \%$ \\
\hline
\end{tabular}

\section{RESULTS}

First, the validity and reliability of multi-item measures were investigated to define the measurement model by examining these indicators such as outer loadings, Cronbach Alpha, composite reliability, and average variance extracted (AVE) (Hair et al., 2014). The discriminant validity can be evaluated by accessing values of the square root of AVE or HTMT (Lewis et al., 2005). When factor loadings surpass 0.7 , convergent validity is appropriate (Hair et al., 2019), and Cronbach's Alpha, Composite reliability would be in good reliability if the values ranged from 0.70 to 0.90 . Moreover, convergent validity is established when the AVE for each latent variable exceeds 0.5 (Fornell \& Larcker, 1981). The result shows that five items were deleted from constructs due to outer loadings less than 0.7 , such as BO5, RA1, RO3, IRC5, JP5. As the outer loading values of the rest 29 items are greater than 0.70 , these items satisfy the convergent validity. Cronbach alpha (CA) values of 7 constructs have ranged from 0.809 to 0.910 , and Composite reliability (CR) values range from 0.875 to 0.933 and satisfy the excellent reliability. All AVE values are more significant than 0.5 , which represents acceptable constructs.

Discriminant validity examines how items distinguish across constructions or quantify separate notions. AVE square roots should be more significant in magnitude than the square roots of any of the variables' correlations for any of the variables in the analysis (Fornell \& Lacker, 1981). As a result, while analyzing the validity of observed measurements, this study used the square roots of AVE coefficients as a starting point. The study discovered that the square root values of all variables are more significant than the correlations in the relevant columns and rows, indicating that all the constructs fulfill the discriminant validity requirement.

Table 2. Analysis of the internal consistency reliability and the convergent validity

\begin{tabular}{|c|c|c|c|c|c|}
\hline Measures & No. of items & Outer loadings & CA & CR & AVE \\
\hline Occupational stress - OS & 4 items & $0.752-0.849$ & 0.831 & 0.887 & 0.662 \\
\hline Parental stress - PS & 4 items & $0.773-0.805$ & 0.809 & 0.875 & 0.636 \\
\hline Burn-out - BO & 4 items & $0.815-0.820$ & 0.835 & 0.890 & 0.669 \\
\hline Role overload - RO & 4 items & $0.851-0.865$ & 0.882 & 0.919 & 0.738 \\
\hline Role Ambiguity - RA & 4 items & $0.804-0.869$ & 0.857 & 0.903 & 0.701 \\
\hline Inter-role conflict - IRC & 4 items & $0.825-0.837$ & 0.850 & 0.899 & 0.690 \\
\hline Job performance - JP & 5 items & $0.843-0.868$ & 0.910 & 0.933 & 0.736 \\
\hline
\end{tabular}

Table 3. Fornell-Larcker criterion

\begin{tabular}{l|c|c|c|c|c|c|c}
\hline Measures & BO & IRC & JP & OS & PS & RA & RO \\
\hline BO & 0.818 & - & - & - & - & - \\
IRC & 0.322 & 0.831 & - & - & - & - \\
JP & -0.545 & -0.608 & 0.858 & - & - & - \\
OS & 0.282 & 0.256 & -0.22 & 0.814 & - & - \\
PS & 0.416 & 0.247 & -0.289 & 0.128 & 0.797 & - \\
RA & 0.251 & 0.536 & -0.398 & 0.285 & 0.193 & 0.837 \\
RO & 0.283 & 0.626 & -0.399 & 0.303 & 0.238 & 0.408 & - \\
\hline
\end{tabular}


Finally, the multicollinearity of formative constructs was assessed. Multicollinearity is evaluated by the variance inflation factor (VIF). According to Hair et al. (2014), a VIF value greater than five tolerance levels indicate multicollinearity, whereas a below threshold of 5 indicates no multicollinearity issues. The VIF values ranged from 1.070 to 1.199 , and all of them were lower than five. Hence, there is no critical collinearity issue among the predictor constructs in the structural model.

Before assessing the structural model, the quality of the structural model was checked by testing the model fit with two model-fitting values: Standardized Root Mean Square Residual (SRMR) and the Normed Fit Index (NFI). Hair et al. (2014) suggested the standard for acceptable fit (SRMR value) should be less than 0.08 . R2 and path coefficients were used to assess the validity of the structural model in which the R2 number represents the percentage of variation explained by the independent factors in the dependent variable, and the path coefficients allow the researcher to confirm or disconfirm each hypothesis and better understand the strength of the relationship between dependent and independent variables. Cohen (1998) claimed that $R 2$ values of $0.26,0.13$, and 0.02 correspond to significant, moderate, and weak predictive accuracy, respectively. The Q2 test was established to assess the predictive significance of endogenous variables, and Q2 quantifies how effectively observed values are rebuilt by the model and its parameter estimations (Vinzi et al., 2010). The blindfolding process in Smart PLS was used to test Q2 values, and according to Akter et al. (2011), the Q2 value should be greater than 0 .

To determine the significance of the regression weights, 5,000 bootstrapped samples from the initial 326 instances are executed. The result of Table 4 showed that the SRMR value of 0.046 - less than the threshold (0.08) indicates the model's good fit for theory testing. $\mathrm{R} 2$ values of $\mathrm{IRC}=0.487, \mathrm{JP}=$ 0.505 represented the substantial level, while R2 value of $\mathrm{BO}=0.258$ represented the moderate level. The R2 of Burnout (BO) is 0.258 means that $25.8 \%$ of burnout is explained by Occupational stress (OS) and Parental stress (PS). 48.7\% of inter-role conflict (IRC) is explained by Role ambiguity (RA) and Role overload (RO), whereas 50.5\% of Job performance (JP) is explained by Burnout (BO) and Inter-role conflict (IRC). All Q2 values of $0.239,0.125$, and 0.225 exceeded 0 , revealing that the Burnout, Inter-role conflict, and Job performance demonstrated acceptable relevance.

Table 4. R2, Q2, and SRMR

\begin{tabular}{l|c:c:c}
\hline Measures & R2 & Q2 & SRMR \\
\hline BO & 0.258 & 0.167 & \\
\hdashline IRC & 0.487 & 0.331 & 0.046 \\
\hline JP & 0.505 & 0.368 & \\
\hline
\end{tabular}

The second criterion for evaluating the structural model is its path coefficient value. Path coefficients ( $\beta$ values) describe the amount of change in the dependent variable as a function of each independent variable. If an impact in the model is to be considered statistically significant, path coefficients must be more than 0.100 . The exclusion of an exogenous variable from a model's model-fitting procedure was studied to see if the endogenous latent variable changed significantly after the exogenous variable was removed from the model. Since the $\mathrm{f} 2$ values of 0.02 and 0.15 suggest modest effects and the $\mathrm{f} 2$ value of 0.35 indicates considerable effects (Cohen, 1988).

The results showed that all independent variables significantly impact dependent variables due to $p$ values less than 0.05 and $\beta$ greater than 0.100 . While Burnout and Inter-role conflict negatively impact job performance, other relationships show

Table 5. Hypotheses testing results

\begin{tabular}{|c|c|c|c|c|c|}
\hline Hypotheses & $\beta$ & $t$ & $f^{2}$ & $p$ & Result \\
\hline$H 1: B O \rightarrow J P$ & -0.390 & 10.823 & 0.216 & 0.000 & Accepted \\
\hline$H 2: I R C \rightarrow J P$ & -0.482 & 13.788 & 0.037 & 0.000 & Accepted \\
\hline $\mathrm{H3}: \mathrm{IRC} \rightarrow \mathrm{BO}$ & 0.189 & 3.851 & 0.132 & 0.000 & Accepted \\
\hline $\mathrm{H} 4: \mathrm{OS} \rightarrow \mathrm{BO}$ & 0.188 & 3.757 & 0.033 & 0.000 & Accepted \\
\hline H5: PS $\rightarrow$ BO & 0.345 & 8.250 & 0.176 & 0.000 & Accepted \\
\hline$H 6: R O \rightarrow I R C$ & 0.489 & 12.688 & 0.069 & 0.000 & Accepted \\
\hline$H 7: R A \rightarrow I R C$ & 0.337 & 7.744 & 0.062 & 0.000 & Accepted \\
\hline
\end{tabular}




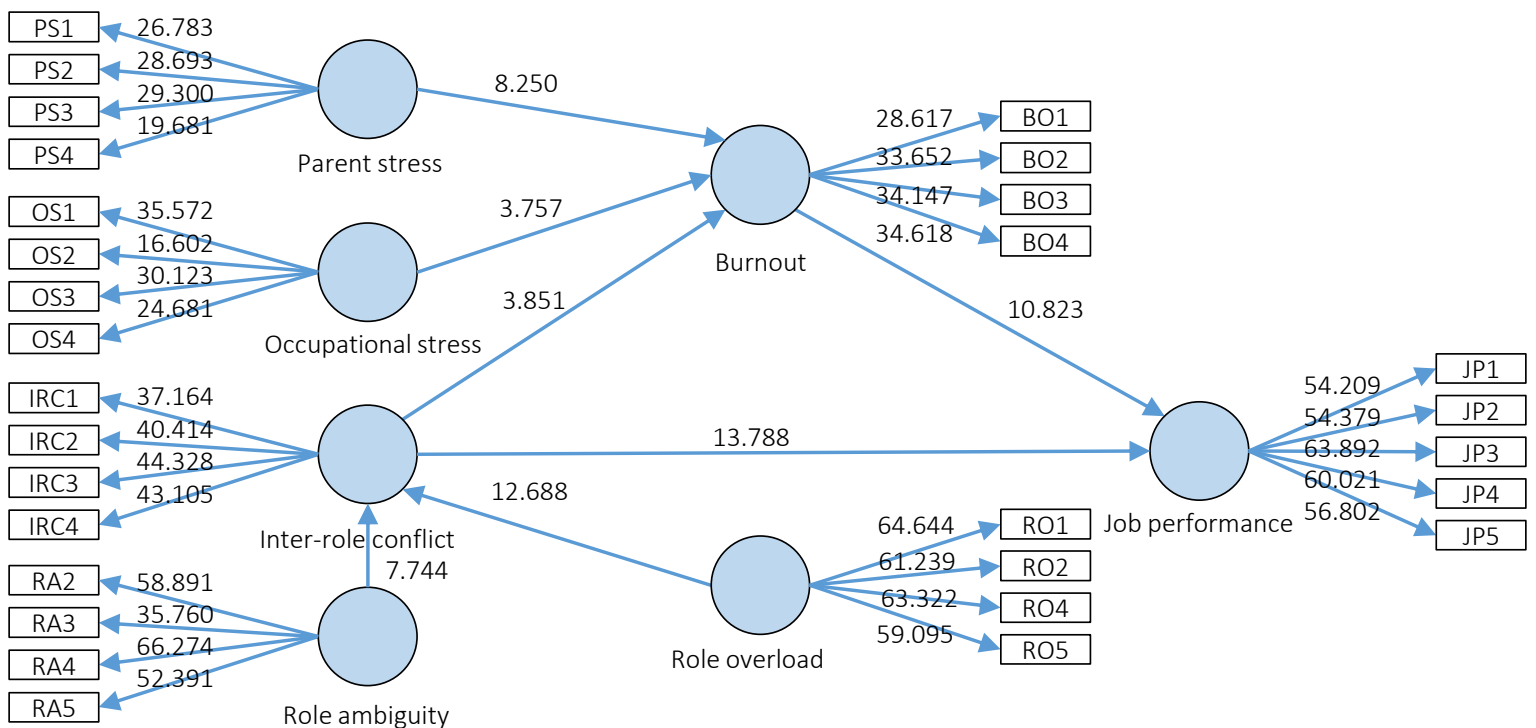

Figure 2. PLS-SEM results

positive effects. The relationship between burnout and job performance is the most robust model with $\beta=-0.390$, whereas occupational stress and burnout have the weakest relationship with burnout ( $\beta$ $=0.188$ ). Moreover, all seven hypotheses are confirmed because of the $p$-value $<0.05$. Considering the effect size of all relationships, it can be recognized that the impact of Burnout on Job performance and role overload on inter-role conflict has a medium to significant impact level. The rest of the five relationships show the small to medium impact due to 22 ranging from 0.02 to 0.15 .

\section{DISCUSSION}

The analysis results noted that:

(i) occupational and parental stress positively and significantly affect burnout. They are consistent with findings from earlier research of Drake and Hebert (2002), Koronaiou and Antoniou (2018), Sriharan et al. (2021), DeaterDeckard and Scarr (1996), Raphael et al. (2010). Evidence was also found that

(ii) role ambiguity and role overload positively influence inter-role conflict. The findings of this study are in line with Netemeyer et al. (1990), Gurbuz et al. (2013), and Lu et al. (2019);

(iii) the significant - negative impacts of burnout and inter-role conflict on job performance.
These findings supported the previous research (Tubre \& Collins, 2000);

(iv) inter-role conflict has a positive and significant impact on burnout. This finding is in line with Jawahar et al. (2012) and Schaufeli et al. (2009). Moreover, both theory and practice can benefit from this research.

Theoretically, a small number of studies have dealt with the three themes of burnout, job performance, or inter-role conflict simultaneously in psychology, human resources, and banking literature. In addition, few studies to date have explored the effects of burnout and inter-role conflict on job performance, especially concerning bankers who have children. Moreover, the impacts of stressors, including occupational stress and parental stress, on burnout symptoms were also examined. In previous research, job-related stress has already been identified as the primary determinant of burnout. However, the stress from parental responsibilities has not popularly been considered one of the burnout's roots. In the normal state, working parents only must fulfill their parenting obligations out of working hours and focus on their work without disturbing their children. However, during social distancing, the pressure and stress from taking care of children have pushed bankers who have children to physical exhaustion, mental instability, and emotional drain. Thus, it is difficult for them to focus on work and complete the parenting task to the best extent. Moreover, this 
study also contributes to the existing role conflict literature by specifying two critical antecedents of inter-role conflict such as role ambiguity and role overload.

Practically, for bank boards of directors and human resource policy makers, this study provides some guidance on better assisting bankers who have children during the tough time of COVID-19 social distance. Four practical suggestions could be considered to better support bankers who have children during COVID-19 social distancing. First, both the banks' board of management and bankers who have children must accept that achieving work-family balance is difficult, especially during the social distancing of COVID-19. The side effects of this imbalance will cause mental stress, health fatigue, conflicts in family relationships, and ultimately reduce job performance. Second, the management board should implement more robust organizational support policies to remove the burden and stress of job-related activities. For example, sharing all necessary information and giving de- tailed guidelines, deadlines, and quality assessment methods for work duties, maintaining constant and mutual effective communication between bankers who have children and management departments to strengthen direct and instant support from banks, and providing web-based and application-based online tools to assure for tasks taking anywhere, anytime. The technology interventions may enhance bankers' work engagement and improve working performance. Third, the administrative workload should be reduced and cut off for bankers during this period. The administrative task is considered a truly "nightmare" for all bankers. It takes a lot of time and effort and causes bankers who have children. Forth, bankers who have children individually should get familiar with saying "No" to the unimportant and taking care of themselves. Because of lacking time, learning how to prioritize things that matter most and say no to things that matter least is an excellent way to manage the limited time. Moreover, self-care is critical and vital during this challenging period, thus relaxing to get the metal rid of stress and health far from fatigue.

\section{CONCLUSION}

Working remotely from home has caused many challenges and obstacles for bankers with children, especially during COVID-19 social distancing. The burden of balancing between work duties and family responsibilities has brought stressors and role conflicts to working parents. This study explores the interrelationship among occupational stress, parental stress, burnout, role overload, role ambiguity, inter-role conflict, and job performance of bankers with children. Despite some notable findings in this study, several limitations must be acknowledged. One potential limitation is the sample size; the findings of this paper are limited to 326 bankers who have children. Hence, they cannot generalize the bankers who have children in Vietnam. Future research should be taken with a more significant number of participants. Second, this study employed just the survey approach; thus, future field research and experimental study should be considered alternatives. Finally, burnout was taken as a mediating variable to explore relationships in the research model.

\section{AUTHOR CONTRIBUTIONS}

Conceptualization: Hai Ninh Nguyen.

Data curation: Hai Ninh Nguyen.

Formal analysis: Hai Ninh Nguyen.

Funding acquisition: Hai Ninh Nguyen.

Investigation: Hai Ninh Nguyen.

Methodology: Hai Ninh Nguyen.

Project administration: Hai Ninh Nguyen.

Resources: Hai Ninh Nguyen.

Writing - original draft: Hai Ninh Nguyen.

Writing - reviewing \& editing: Hai Ninh Nguyen. 


\section{REFERENCES}

1. Abramis, D. J. (1994). Work role ambiguity, job satisfaction, and job performance: Meta-analyses and review. Psychological Reports, 75(3), 1411-1433. https://doi. org/10.2466/pr0.1994.75.3f.1411

2. Ahuja, M. K., Chudoba, K. M., Kacmar, C. J., McKnight, D. H., \& George, J. F. (2007). IT road warriors: Balancing workfamily conflict, job autonomy, and work overload to mitigate turnover intentions. MIS Quarterly, 31(1), 1-17. https://doi. org/10.2307/25148778

3. Ajila, C., \& Abiola, A. (2004). Influence of rewards on workers performance in an organization. Journal of Social Sciences, 8(1), 7-12. https://doi.org /10.1080/09718923.2004.11892397

4. Akter, S., D’Ambra, J., \& Ray, P. (2011). Trustworthiness in mHealth information services: an assessment of a hierarchical model with mediating and moderating effects using partial least squares (PLS). Journal of the American Society for Information Science and Technology, 62(1), 100-116. https:// doi.org/10.1002/asi.21442

5. Ammons, S. K., \& Markham, W. T. (2004). Working at home: Experiences of skilled white collar workers. Sociological Spectrum, 24(2), 191-238. https://doi. org/10.1080/02732170490271744

6. Andersen, O., \& Kheam, L. S. (1998). Resource-based theory and international growth strategies: an exploratory study. International Business Review, 7(2), 163-184. https://doi.org/10.1016/ S0969-5931(98)00004-3

7. Arnold, J., Silvester, J., Cooper, C. L., Robertson, I. T., \& Patterson, F. M. (2005). Work psychology: Understanding human behaviour in the workplace. Pearson Education. Retrieved from https:// pureportal.coventry.ac.uk/en/ publications/work-psychologyunderstanding-human-behaviourin-the-workplace-6t

8. Berry, J. O., \& Jones, W. H. (1995). The parental stress scale: Initial psychometric evidence. Journal of Social and Personal Relationships, 12(3), 463-472. https://doi. org/10.1177/0265407595123009

9. Bolman, L. G., \& Deal, T. E. (2017). Reframing organizations: Artistry, choice, and leadership. John Wiley \& Sons.

10. Borman, W. C., \& Motowidlo, S. J. (1997). Task performance and contextual performance: The meaning for personnel selection research. Human Performance, 10(2), 99-109. https://doi.org/10.1207/ s15327043hup1002_3

11. Bowling, N. A., Khazon, S., Alarcon, G. M., Blackmore, C. E., Bragg, C. B., Hoepf, M. R., \& Li, H. (2017). Building better measures of role ambiguity and role conflict: The validation of new role stressor scales. Work \& Stress, 31(1), 1-23. https://doi.org/10.1080/02678373. 2017.1292563

12. Boyle, G. J., Borg, M. G., Falzon, J. M., \& Baglioni Jr, A. J. (1995). A structural model of the dimensions of teacher stress. British Journal of Educational Psychology, 65(1), 49-67. https:// doi.org/10.1111/j.2044-8279.1995. tb01130.x

13. Chung, C. O. Y., Ping, D. C., Zahari, P. S., Ravindran, T. S., \& Kannathasan, K. (2020). The Association Between Self-esteem and Banker Stress Among Undergraduate Medical Students. International Journal of Biomedical and Clinical Sciences, 5(2), 6474. Retrieved from http://www. aiscience.org/journal/paperInfo/ ijbcs?paperId $=4800$

14. Cluver, L., Lachman, J. M., Sherr, L., Wessels, I., Krug, E., Rakotomalala, S., Blight, S., Hillis, S., Bachman, G., Green, O., Butchart, A., Tomlinson, M., Ward, C. L., Doubt, J., \& McDonald, K. (2020). Parenting in a time of COVID-19. Lancet, 395, 10231. https://doi.org/10.1016/ s0140-6736(20)30736-4
15. Cohen, J. (1988). Statistical power analysis for the behavioral sciences. Hillsdale, NJ: Lawrence Erlbaum.

16. Cropanzano, R., Rupp, D. E., \& Byrne, Z. S. (2003). The relationship of emotional exhaustion to work attitudes, job performance, and organizational citizenship behaviors. Journal of Applied Psychology, 88(1), 160-169. https://doi.org/10.1037/00219010.88.1.160

17. De Silva, N., Samanmali, R., \& De Silva, H. L. (2017). Managing occupational stress of professionals in large construction projects. Journal of Engineering, Design and Technology, 15(4), 488-504. https://doi.org/10.1108/ JEDT-09-2016-0066

18. Deadrick, D. L., \& Gardner, D. G. (1999). Performance distributions: measuring employee performance using total quality management principles. Journal of Quality Management, 4(2), 225-241. https://doi.org/10.1016/S10848568(99)00014-0

19. Deater-Deckard, K., \& Scarr, S. (1996). Parenting stress among dual-earner mothers and fathers: Are there gender differences? Journal of Family Psychology, 10(1), 45-59. https://doi.apa.org/ doi/10.1037/0893-3200.10.1.45

20. Drake, D., \& Hebert, E. P. (2002). Perceptions of occupational stress and strategies for avoiding burnout: Case studies of two female teacher-coaches. Physical Educator, 59(4), 170-183.

Retrieved from https://www. proquest.com/openview/a548535c f25f85fd834f30c3d674d671/1?pqorigsite $=$ gscholar $\& \mathrm{cbl}=2030480$

21. Fimian, M. J. (1984). The development of an instrument to measure occupational stress in teachers: The Teacher Stress Inventory. Journal of Occupational Psychology, 57(4), 277-293. https:// doi.org/10.1111/j.2044-8325.1984. tb00169.x

22. Fornell, C., \& Larcker, D. F. (1981). Evaluating structural equation models with unobservable 
variables and measurement error. Journal of Marketing Research, 18(1), 39-50. https://doi. org/10.2307/3151312

23. Freudenberger, H. J. (1974). Staff burnout. Journal of Social Issues, 30(1), 159-165. https://doi. org/10.1111/j.1540-4560.1974 tb00706.x

24. Fujiwara, K., Tsukishima, E., Tsutsumi, A., Kawakami, N., \& Kishi, R. (2003). Interpersonal conflict, social support, and burnout among home care workers in Japan. Journal of Occupational Health, 45(5), 313 320. https://doi.org/10.1539/ joh. 45.313

25. Garbe, A., Ogurlu, U., Logan, N., \& Cook, P. (2020). COVID-19 and remote learning: Experiences of parents with children during the pandemic. American Journal of Qualitative Research, 4(3), 45-65. https://doi.org/10.29333/ajqr/8471

26. Gurbuz, S., Turunc, O., \& Celik, M. (2013). The impact of perceived organizational support on workfamily conflict: Does role overload have a mediating role? Economic and Industrial Democracy, 34(1), 145-160. https://doi. org/10.1177/0143831X12438234

27. Hair Jr, J. F., Sarstedt, M., Hopkins, L., \& Kuppelwieser, V. G. (2014). Partial least squares structural equation modeling (PLS-SEM): An emerging tool in business research. European Business Review, 26(2), 106-121. https://doi. org/10.1108/EBR-10-2013-0128

28. Hair, J. F., Risher, J. J., Sarstedt, M., \& Ringle, C. M. (2019). When to use and how to report the results of PLS-SEM. European Business Review, 31(1), 2-24. https://doi. org/10.1108/EBR-11-2018-0203

29. Holly, L. E., Fenley, A. R., Kritikos, T. K., Merson, R. A., Abidin, R. R., \& Langer, D. A. (2019). Evidencebase update for parenting stress measures in clinical samples. Journal of Clinical Child \& Adolescent Psychology, 48(5), 685-705. https://doi.org/10.1080/1 5374416.2019.1639515

30. Honkonen, T., Ahola, K., Pertovaara, M., Isometsä, E.,
Kalimo, R., Nykyri, E., Aromaa, A., \& Lönnqvist, J. (2006). The association between burnout and physical illness in the general population - results from the Finnish Health 2000 Study. Journal of Psychosomatic Research, 61(1), 59-66. https:// doi.org/10.1016/j.jpsychores.2005.10.002

31. House, R. J., \& Rizzo, J. R. (1972). Role conflict and Ambiguity as critical variables in a model of organizational behavior. Organizational Behavior and Human Performance, 7(3), 467-50. https://doi.org/10.1016/00305073(72)90030-X

32. Jackson, S. E., \& Schuler, R. S. (1983). Preventing employee burnout. Personnel, 60(2), 58-68. Retrieved from https://pubmed. ncbi.nlm.nih.gov/10261205/

33. Jawahar, I. M., Kisamore, J. L., Stone, T. H., \& Rahn, D. L. (2012). Differential effect of inter-role conflict on proactive individual's experience of burnout. Journal of Business and Psychology, 27(2), 243-254. https://doi.org/10.1007/ s10869-011-9234-5

34. Kahn, R. L., Wolfe, D. M., Quinn, R. P., Snoek, J. D., \& Rosenthal, R. A. (1964). Organizational stress: Studies in role conflict and Ambiguity. John Wiley. Retrieved from https://psycnet.apa.org/record/1965-08866-000

35. Katz, D., \& Kahn, R. L. (1978). The Social Psychology of Organizations (p. 528). New York: Wiley.

36. Koronaiou, P., \& Antoniou, A. S. (2018). Investigating burnout/ occupational stress in relation to emotional intelligence and coping strategies in Greek nurses. Dialouges in Clinical Neuroscience \& Mental Health, 1(1), 38-51. https://doi.org/10.26386/obrela. vli1.7

37. Kremer, I. (2016). The relationship between school-work-familyconflict, subjective stress, and burnout. Journal of Managerial Psychology, 31(4), 805-819. https:// doi.org/10.1108/JMP-01-20150014
38. Lee, R. T., \& Ashforth, B. E. (1996). A meta-analytic examination of the correlates of the three dimensions of job burnout. Journal of Applied Psychology, 81(2), 123-133. https://doi.org/10.1037/00219010.81.2.123

39. Lewis, B. P., Burge, C. B., \& Bartel, D. P. (2005). Conserved seed pairing, often flanked by adenosines, indicates that thousands of human genes are microRNA targets. Cell, 120(1), 15-20. https://doi.org/10.1016/j. cell.2004.12.035

40. Lu, R., Wang, Z., Lin, X., \& Guo, L. (2019). How do family role overload and work interferance with family affect the life satisfaction and sleep sufficiency of construction professionals? International Journal of Environmental Research and Public Health, 16(17), 3094. https://dx.doi.org/10.3390/ ijerph16173094

41. Maslach, C., \& Jackson, S. E. (1981). The measurement of experienced burnout. Journal of Organizational Behavior, 2(2), 99-113. https://doi.org/10.1002/ job.4030020205

42. Maslach, C., Schaufeli, W. B., \& Leiter, M. P. (2001). Job burnout. Annual Review of Psychology, 52(1), 397-422. https://doi.org/10.1146/annurev. psych.52.1.397

43. Netemeyer, R. G., Johnston, M. W., \& Burton, S. (1990). Analysis of role conflict and role ambiguity in a structural equations framework. Journal of Applied Psychology, 75(2), 148-157. https://doi.org/10.1037/00219010.75.2.148

44. Nguyen, H. N., \& Tran, M. D. (2021). The Effect of Perceived Organizational Support on Employee Engagement During the COVID-19 Pandemic: An Empirical Study in Vietnam. The Journal of Asian Finance, Economics and Business, 8(6), 415-426. https://doi.org/10.13106/ jafeb.2021.vol8.no6.0415

45. Nilsen, H. R., \& Ringholm, T. (2019). Lost in motivation? The 
case of a Norwegian community healthcare project on ethical reflection. Cogent Business \& Management, 6(1), 1632045. https://doi.org/10.1080/23311975. 2019.1632045

46. Osman, S., Shariff, S. H., \& Lajin, M. N. A. (2016). Does innovation contribute to employee performance? Procedia-Social and Behavioral Sciences, 219, 571-579. https://doi.org/10.1016/j.sbspro.2016.05.036

47. Raphael, J. L., Zhang, Y., Liu, H., \& Giardino, A. P. (2010). Parenting stress in US families: Implications for paediatric healthcare utilization. Child: Care, Health and Development, 36(2), 216-224. https://doi.org/10.1111/j.13652214.2009.01052.x

48. Ryan, T. D. (2008). Antecedents for interrole conflict in the high school teacher/coach. Physical Educator, 65(2), 58-67. Retrieved from https://eric. ed.gov/?id=EJ894304

49. Saetang, J., Sulumnad, K., Thampitak, P., \& Sungkaew, T. (2010). Factors affecting perceived job performance among staff: A case study of Ban Karuna Juvenile Vocational Training Centre for boys. The Journal of Behavioral Science, 5(1), 33-45. Retrieved from https://so06.tci-thaijo.org/ index.php/IJBS/article/view/2200

50. Schaufeli, W. B., Bakker, A. B., \& Van Rhenen, W. (2009). How changes in job demands and resources predict burnout, work engagement, and sickness absenteeism. Journal of Organizational Behavior, 30(7), 893-917. https://doi.org/10.1002/ job.595

51. Schaufeli, W., \& Enzmann, D. (1998). The burnout companion to study and practice: A critical analysis. CRC press.

52. Sriharan, A., Ratnapalan, S., Tricco, A. C., \& Lupea, D. (2021). Women in healthcare experiencing occupational stress and burnout during COVID-19: a rapid review. BMJ Open, 11(4), e048861. https://doi.org/10.1136/ bmjopen-2021-048861

53. Srivastav, A. K. (2006).

Organizational climate as a dependent variable: Relationship with role stress, coping strategy and personal variables. Journal of Management Research, 6(3), 125136. Retrieved from https://managementresearch.co.in/download/ organizational-climate-as-adependent-variable-relationship-with-role-stress-copingstrategy-and-personal-variables/

54. Tubre, T. C., \& Collins, J. M. (2000). Jackson and Schuler (1985) revisited: A meta-analysis of the relationships between role ambiguity, role conflict, and job performance. Journal of Management, 26(1), 155-169. https://doi.org/10.1016/S01492063(99)00035-5

55. Vinzi, V. E., Trinchera, L., \& Amato, S. (2010). PLS path modeling: from foundations to recent developments and open issues for model assessment and improvement. In Handbook of Partial Least Squares (pp. 47-82) Springer, Berlin, Heidelberg. https://doi.org/10.1007/978-3540-32827-8_3 